\title{
THE IMPORTANCE OF ANTENATAL ULTRASOUND SCREENING FOR CONGENITAL OSTEOCHONDRODYSPLASIA - TWO CASE REPORTS
}

\author{
VAŽNOST ULTRAZVUČNOG ANTENATALNOG PROBIRA \\ NA KONGENITALNE OSTEOHONDRODISPLAZIJE \\ - PRIKAZ DVAJU BOLESNIKA
}

\author{
Ivka Djaković ${ }^{1}$, Vesna Gall ${ }^{1}$, Vanja Saftić ${ }^{2}$, Petra Radulović ${ }^{3}$, Nada Bilić ${ }^{4}$, Vesna Košec ${ }^{1}$ \\ ${ }^{1}$ Department of Gynecology and Obstetrics, Sestre Milosrdnice University Hospital Center, Zagreb, Croatia \\ / Klinika za ženske bolesti i porodništvo, Klinički bolnički centar Sestre milosrdnice, Zagreb, Hrvatska \\ ${ }^{2}$ Child Protection Center of Zagreb, Zagreb, Croatia / Poliklinika za zaštitu djece, Zagreb, Hrvatska \\ ${ }^{3}$ Ljudevit Jurak Department of Pathology, Sestre Milosrdnice University Hospital Center, Zagreb, Croatia \\ / Klinički zavod za patologiju „Ljudevit Jurak“, Klinički bolnički centar Sestre milosrdnice, Zagreb, Hrvatska \\ ${ }^{4}$ Department of Anesthesiology and Intensive Care, Sestre Milosrdnice University Hospital Center, Zagreb, Croatia \\ / Zavod za anesteziologiju, intenzivnu medicinu i liječenje boli, Klinički bolnički centar Sestre milosrdnice, Zagreb, Hrvatska
}

\author{
Corresponding author / Adresa autora za dopisivanje: \\ Vesna Gall \\ Department of Gynecology and Obstetrics / Klinika za ženske bolesti i porodništvo \\ Sestre Milosrdnice University Hospital Center / Klinički bolnički centar Sestre milosrdnice \\ Vinogradska 29 \\ 10000 Zagreb, Croatia / Hrvatska
}

Tel. / Phone: +38513787361

Fax number / Faks: +38513768272

E-mail: gall.vesna@gmail.com

Received / Primljeno: June 8, 2018 / 8. 6. 2018. Accepted / Prihvaćeno: January 9, 2019 / 9. 1. 2019.

\section{ABstract}

Osteochondrodysplasias comprise a large, genetically heterogeneous group of disorders characterized by abnormalities of cartilage and bone growth. They are often associated with abnormalities in other organ systems. They are classified as lethal or non-lethal skeletal dysplasias. Thanatophoric dysplasia is the most common form of lethal skeletal dysplasia with an incidence of 0.69 per 10.000 births. Heterozygous achondroplasia is the most common non-lethal dysplasia with an incidence of 0.15 per 10.000 births. We will present two cases of skeletal dysplasia. The first case is the case of lethal osteochondrodysplasia in the fetus of a 41-year-old multiparous woman, who came to our hospital in active preterm labor, in the $33^{\text {th }}$ week of uncontrolled pregnancy. The second case is the case of non-lethal osteochondrodysplasia in the fetus of a 31-year-old multiparous woman. The fetal short femur length was detected in the $30^{\text {th }}$ week of pregnancy.

KeYwords: Thanatophoric dysplasia - diagnostic imaging; Achondroplasia - diagnostic imaging; Ultrasonography, prenatal - methods; Imaging, three-dimensional; Fetal diseases - diagnostic imaging; Bone and bones abnormalities

\section{SAŽETAK}

Osteohondrodisplazije velika su skupina rijetkih genskih bolesti karakterizirana poremećajem rasta i razvoja hrskavice i kosti. Često su povezane s malformacijama drugih organskih sustava. Mogu se podijeliti na letalne i neletalne skeletne displazije. Tanatoforična displazija jedna je od najčešćih letalnih skeletnih displazija s učestalošću pojavljivanja od 0,69 na 10.000 porođaja, dok je heterozigotna ahondrodisplazija među najčešćim neletalnim displazijama s učestalošću od 0,15 na 10.000 porođaja. Prikazat ćemo dva novorođenčeta s osteohondrodisplazijom. Prvi je prikaz letalne osteohondrodisplazije kod novorođenčeta 41-godišnje višerotkinje koja je u 33. tjednu nekontrolirane trudno- 
će došla u našu Kliniku zbog započetog porođaja. Drugi je prikaz neletalne osteohondrodisplazije u novorođenčeta 31-godišnje višerotkinje kod kojeg se od 30. tjedna trudnoće prate kraće kosti udova.

KLJUČNE RIJEČI: Tanatoforična displazija - dijagnostički slikovni prikaz; Ahondroplazija - dijagnostički slikovni prikaz; Prenatalna ultrasonografija - metode; Trodimenzionalni slikovni prikaz; Fetusne bolesti - dijagnostički slikovni prikaz; Kosti - anomalije

\section{INTRODUCTION}

Skeletal dysplasias comprise a heterogeneous group of disorders characterized by abnormalities of cartilage and bone growth, resulting in an abnormal shape and size of the skeleton and disproportion of the long bones, spine, and head $(1,2)$. These disorders affect approximately $2.4-4.5$ in 10,000 births (3). The classification of skeletal dysplasia is extremely difficult due to the large number of diseases and diverse ways of expressing and overlapping of their features (4-6). In 1997, the International Working Group on Bone Dysplasias proposed a newly revised "International Nomenclature and Classification of the Osteochondrodysplasias" $(7,8)$. The diseases were classified based on the gene and/or genetic disorders. The classification and nomenclature must be constantly updated due to the increasing number of molecular discoveries. This classification includes about 300 disorders, about 50 of which are recognizable at birth. Some skeletal dysplasias are hereditary, and family history is very important. Advancements in technology and the introduction of ultrasound in pregnancy monitoring have enabled very early detection and monitoring of skeletal dysplasia. These disorders begin to manifest in the early stages of fetal development (9). Most of the skeleton begins to ossify early in the development, which can be detected by ultrasound examination. With respect to their prognosis and clinical outcomes, there are two groups of skeletal dysplasias: lethal and nonlethal dysplasias.

The most common types of lethal skeletal dysplasias are thanatophoric dysplasia, homozygous achondroplasia, achondrogenesis, osteogenesis imperfecta types II and III, perinatal lethal hypophosphatasia, and short rib polydactyly syndrome. The main characteristic of these types of lethal skeletal dysplasias is that death occurs while in utero, during childbirth, or shortly after birth.

The most common types of non-lethal skeletal dysplasias are heterozygous achondroplasia and osteogenesis imperfecta types I and IV. They are characterized by subsequent disability and chronic diseases of the locomotor system (2).

We report two cases of skeletal dysplasia diagnosed prenatally, one with a lethal outcome and one with a non-lethal outcome.

\section{UVOD}

Skeletne displazije heterogena su skupina bolesti obilježena poremećenim rastom i razvojem hrskavice i kostiju, s posljedično abnormalnim oblikom i abnormalnom veličinom skeleta te disproporcijom dugih kostiju, kralježnice i lubanje $(1,2)$. Ovi se poremećaji pojavljuju u približno $2,4-4,5$ novorođenčadi na 10.000 porođaja (3). Klasifikacija skeletnih displazija iznimno je teška zbog velikog broja takvih poremećaja te njihove raznolike ekspresije i preklapanja obilježja $(4-6)$. Međunarodna radna skupina za koštane displazije (engl. the International Working Group on Bone Dysplasias) predložila je 1997. godine novu, revidiranu klasifikaciju osteohondrodiplazija prema genskim i/ili genetičkim poremećajima pod naslovom „Međunarodna nomenklatura i klasifikacija osteohondrodisplazija" (engl. International Nomenclature and Classification of the Osteochondrodysplasias) $(7,8)$. Budući da se sve više poremećaja otkriva na molekularnoj razini, tako se klasifikacija i nomenklatura neprekidno moraju obnavljati. Spomenuta klasifikacija uključuje tristotinjak poremećaja od kojih je pedesetak prepoznatljivo odmah nakon rođenja. Osifikacija skeleta započinje u ranoj fazi fetalnog razvoja. Napredak tehnologije i uvođenje ultrazvuka u praćenje trudnoće omogućili su izrazito rano otkrivanje skeletnih displazija i njihovo praćenje od ranih stadija fetalnog razvoja kada započinje osifikacija skeleta i kada se displazije počinju manifestirati (9). S obzirom na prognozu i klinički ishod, postoje dvije skupine skeletnih displazija: letalne i neletalne.

Najčešće vrste letalnih skeletnih displazija jesu tanatoforična displazija, homozigotna ahondroplazija, ahondrogeneza, osteogenesis imperfecta tipa II i III, perinatalna letalna hipofosfatazija i sindrom kratkog rebra s polidaktilijom. Glavno obilježje ovih vrsta letalnih skeletnih displazija jest da smrt nastupa intrauterino, tijekom porođaja ili neposredno nakon njega.

Najčešće vrste neletalnih skeletnih displazija jesu heterozigotna ahondroplazija i osteogenesis imperfecta tipa I i IV. Njihove su značajke kasnija onesposobljenost i kronične bolesti lokomotornog sustava (2).

Prikazujemo dva bolesnika s prenatalno dijagnosticiranom skeletnom displazijom, u jednoga s letalnim, a u drugoga s neletalnim ishodom. 


\section{Case 1}

A 41-year-old multiparous woman was admitted to our hospital in active preterm labor in the $33^{\text {rd }}$ week of gestation from uncontrolled pregnancy. She had three prior uncomplicated pregnancies and two artificial abortions. An ultrasound examination after admission revealed a short femur and polyhydramnios. Femur length (FL) was $27 \mathrm{~mm}$ for $18+2 / 7$ weeks of gestation, while the biparietal diametar (BPD) and the abdominal circumference (AC) were normal for the gestational age. The amniotic fluid index (AFI) was $35 \mathrm{~cm}$ ( $>90$ th percentile). The male infant was delivered vaginally two hours after admission (weight $2050 \mathrm{~g}$, length $36 \mathrm{~cm}$, Apgar score 2, 1, 1). After unsuccessful resuscitation, the newborn died. The performed chest X-ray showed homogeneous opacities in both lungs without ventilated lung parenchyma. The clinical examination revealed disproportionately short arms and legs, a narrow chest, curved thigh bones, flattened bones of the spine (platyspondyly) and shortened thoracic ribs, as well as the typical "telephone-shaped" long bones. The description is consistent with thanatophoric dysplasia type I. The cause of death was respiratory failure (Figure 1).

\section{Case 2}

A 31-year-old multiparous woman was admitted to our hospital in the $37^{\text {th }}$ week of gestation after an ultrasound examination that showed short femur length in the fetus. She had two prior uncomplicated pregnancies. The short femur length was first noticed in the $30^{\text {th }}$ week of gestation. The ultrasound revealed FL of $54 \mathrm{~mm}$ at $28+5 / 7$ weeks of gestation and humerus length (HL) of $49 \mathrm{~mm}$ at $28+6 / 7$ weeks of gestation $\left(<3^{\text {rd }}\right.$ percentile). $\mathrm{BPD}$ and $\mathrm{AC}$ were normal for the gestational age. Other morphology and AFI were normal. The woman vaginally delivered a male infant (weight $3310 \mathrm{~g}$, length 49 $\mathrm{cm}$, Apgar score 10,10$)$ in the $39^{\text {th }}$ week of pregnancy. There were morphological signs of achondroplasia including short upper arms and legs (rhizomelic type), a typical trident hand (Figure 2), an enlarged neurocranium, frontal bossing, flattened nasal bridge, flattened anteroposterior diameter of the chest, protruding abdomen, and mid-face hypoplasia (Figure 3).

\section{DISCUSSION}

In early fetal development, the appearance and shape of long bones require special attention. Ultrasound examination in suspected skeletal dysplasia should include measurement of all long bones, classification of the shortening, and an evaluation of bone quality and presence of bone fractures (1). Attention should also be paid to the appearance of the chest and the size of the heart. A detailed evaluation of the skull and the

\section{Bolesnik 1}

Četrdesetjednogodišnja višerotkinja primljena je u našu Kliniku u 33. tjednu nekontrolirane trudnoće zbog preuranjenog početka porođaja. Prethodne tri trudnoće protekle su bez komplikacija, a imala je i dva namjerna pobačaja. Ultrazvučnim pregledom nakon prijma otkriveni su kratki femur i polihidramnion. Duljina femura (LF) ploda iznosila je $27 \mathrm{~mm}$ u tjednu gestacije $18+2 / 7$, dok su biparijetalni promjer (BPD) $i$ abdominalna cirkumferencija (AC) bili primjereni gestacijskoj dobi. Indeks plodne vode iznosio je $35 \mathrm{~cm}$ ( $>90$. percentila). Novorođenče muškog spola porođeno je vaginalnim putem dva sata nakon prijma (tjelesne mase od $2050 \mathrm{~g}$ i duljine $36 \mathrm{~cm}$, Apgarina indeksa 2/1/1). Nakon neuspješne resuscitacije novorođenče je preminulo. Rendgenska snimka srca i pluća pokazala je homogena zasjenjenja u oba plućna krila bez vidljive prozračnosti plućnog parenhima. Tijekom kliničkog pregleda opazili smo neproporcionalno kratke ruke i noge, uzak prsni koš, zakrivljene natkoljenične kosti, platispondiliju (izravnanje kralježaka) i kratka torakalna rebra te atipičan izgled dugih kostiju u obliku „telefonske slušalice“. Opis odgovara tanatoforičnoj displaziji tipa I. Uzrok smrti bilo je respiratorno zatajenje (slika 1.).

\section{Bolesnik 2}

U našu Kliniku primljena je 31-godišnja višerotkinja u 37. tjednu gestacije nakon što je na ultrazvučnom pregledu kod fetusa otkrivena skraćena duljina femura. Prvi je put to bilo opaženo u 30. tjednu gestacije. Prethodno je imala dvije nekomplicirane trudnoće. Duljina femura (FL) izmjerena ultrazvukom iznosila je $54 \mathrm{~mm}$ u tjednu gestacije $28+5 / 7$, dok je duljina humerusa (HL) bila $49 \mathrm{~mm}$ u tjednu gestacije $28+6 / 7$ (<3. percentila). BPD i AC bili su normalni za gestacijsku dob. Druge morfološke značajke i AFI bili su primjereni. Vaginalnim porođajem rođen je dječačić (težak $3310 \mathrm{~g}$ i dugačak $49 \mathrm{~cm}$, Apgarina indeksa 10/10) u 39. tjednu trudnoće. Odmah su bili vidljivi znakovi ahondroplazije: kratke nadlaktice i noge (rizomeličnog tipa), tipičan trozubi izgled šake (slika 2.), povećani neurokranij, izražene čeone izbočine, splošteni hrbat nosa, smanjen anteroposteriorni promjer prsnog koša, protrudirani abdomen i hipoplazija središnjeg dijela lica (slika 3.).

\section{RASPRAVA}

U ranom stadiju fetalnog razvoja potrebno je obratiti pozornost na izgled i oblik dugih kostiju. Ultrazvučni pregled pri sumnji na skeletnu displaziju uključuje mjerenje svih dugih kostiju, kategorizaciju skraćenja kosti i procjenu njihove kvalitete te eventualnih koštanih fraktura (1). Isto je tako potrebno procijeniti 


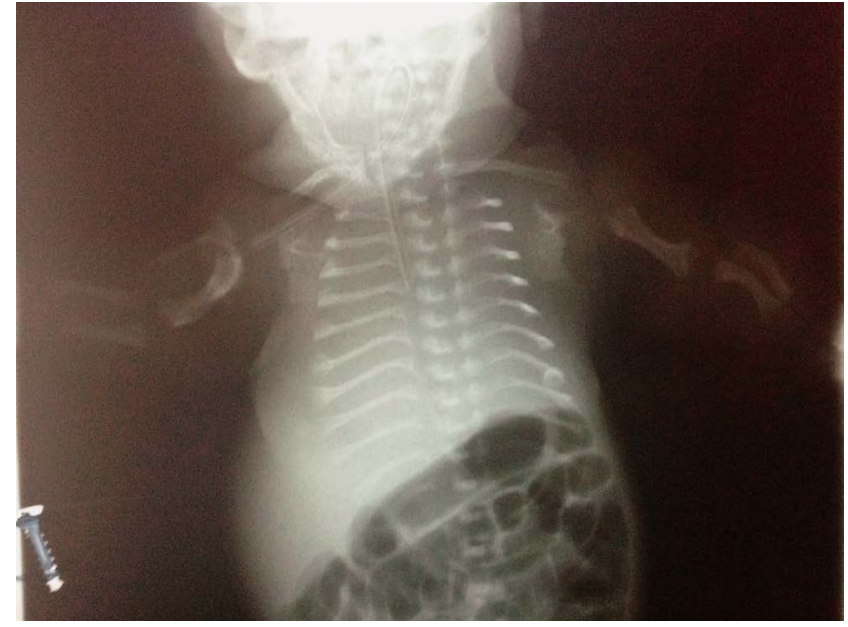

Figure 1. Chest X-ray of a newborn with thanatophoric dysplasia type I showed homogeneous opacities in both lungs without ventilated lung parenchyma.

SLIKA 1. Rendgenska slika novorođenčeta s tanatoforičnom displazijom tipa I pokazuje homogena zasjenjenja u oba plućna krila bez ventilacije plućnog parenhima

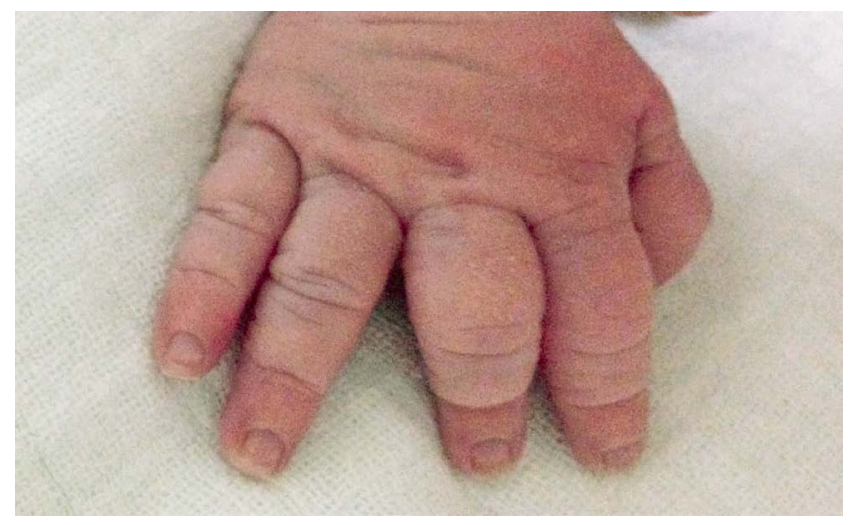

Figure 2. Typical trident hand in a newborn with achondroplasia.

SLIKA 2. Tipična ruka poput trozupca u novorođenčeta s ahondroplazijom

shape of the hands and feet is important, as well as an examination of the abdominal organs and amniotic fluid index. Polyhydramnion, intrauterine growth restriction, ventriculomegaly, flattened chest, and micromelia are often associated with skeletal dysplasia and can be diagnosed with 2D ultrasound. With the help of 3D ultrasound, morphological characteristics such as flattened facial features, hypoplastic ribs, and scapular anomalies can be detected. 3D-CT can provide more detailed images, but its use is controversial in the prenatal period.

The involvement of the affected bone segments can be divided into five classes: rhizomelic, mesomelic, acromelic, acromesomelic, or micromelic shortening (10).

Skeletal dysplasias are often associated with one or more of these conditions: head anomalies (craniosynostosis, disproportionally large head), cataract, myo-

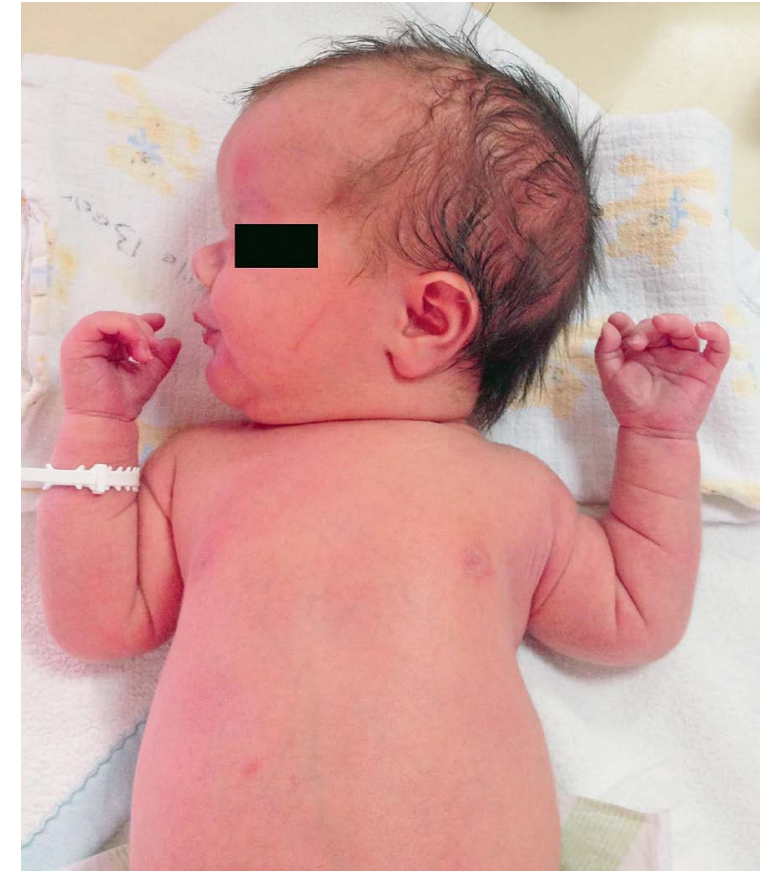

FIGURE 3. Newborn with achondroplasia. The neonate has an enlarged neurocranium, short upper arms, frontal bossing,

flattened nasal bridge, flattened anteroposterior diameter of the chest, protruding abdomen, and midface hypoplasia. SLIKA 3. Novorođenče s ahondroplazijom. Novorođenče ima povećani neurokranij, kratke gornje udove, izbočen frontalni dio, splošteni hrbat nosa, smanjen anteroposteriorni promjer prsnog koša, izbočeni trbuh i hipoplaziju sredine lica

izgled prsnog koša i veličinu srca. Važni su detaljan pregled lubanje, oblika šaka i stopala, kao i abdominalnih organa te indeks plodne vode. Polihidramnion, intrauterini zastoj u rastu, ventrikulomegalija, splošteni prsni koš i mikromelija često su povezani sa skeletnom displazijom i mogu se dijagnosticirati 2D ultrazvukom. S pomoću $3 \mathrm{D}$ ultrazvuka mogu se otkriti morfološke značajke poput sploštenog lica, hipoplastičnih rebara i anomalija lopatice. Detaljnije snimke mogu se dobiti 3D kompjutorskom tomografijom $(\mathrm{CT})$, ali upotreba te metode u prenatalnom razdoblju još je sporna.

Stupanj zahvaćenosti kosti može se podijeliti u pet kategorija: rizomelično, mezomelično, akromelično, akromezomelično i mikromelično skraćenje (10).

Skeletne displazije često su povezane s jednim ili više ovih stanja: anomalije glave (kraniosinostoza, neproporcionalno velika glava), katarakta, miopija, rascjep usne i nepca, mentalna retardacija, atrijski septalni defekt, perzistentni ductus arteriosus, transpozicija velikih krvnih žila, Majewskijev sindrom, polidaktilija, sindaktilija, abducirani (tzv. autostoperski) palac na ruci ili nozi i ostalo.

Incidencija tanatoforične displazije iznosi 1 na $30.000-50.000$ živorođenih. Značajke ove vrste displazije jesu kratki udovi (20 tjedana gestacije), velika glava, kratak vrat, uski prsni koš, izrazite čeone izboči- 
pia, cleft lip and palate, mental retardation, atrial septal defect, ductus arteriosus persistens, transposition of the big vessels, Majewsky syndrome, polydactyly, syndactyly, hitchhiker or abducted thumb/first toe, and others.

Thanatophoric dysplasia has an incidence of 1 per 30,000 to 1 per 50,000 live births. It is characterized by short-limb dysplasia (20 weeks of gestation), a large head, short neck, narrow thorax, frontal bossing, midface hypoplasia, short and small fingers, thin flattened vertebrae, short ribs and bones, a short and curved femur ("telephone-shaped"), macrocranium, normal trunk length, normal mineralization, and no fractures. It is associated with brain abnormalities, and the presence of polyhydramnion in $50 \%$ of the cases (11). Newborns with thanatophoric dysplasia are either stillborn or die shortly after birth due to severe respiratory insufficiency from a reduced thoracic capacity and hypoplastic lungs $(12,13)$.

Heterozygous achondroplasia has an autosomal dominant mode of inheritance. It is a short-limb dysplasia (by 20 weeks of gestation) with typical features such as short rhizomelic arms and legs, enlarged neurocranium, frontal bossing, significant macrocranium, flattening of the nasal bridge, mid-face hypoplasia, flattening of the anteroposterior diametar of the chest, and protruding abdomen.

In the first case, the final diagnosis was confirmed by pathological examination and diagnosis. In the second case, the diagnosis was made after the delivery on the basis of typical morphological signs, but the final diagnosis has to be confirmed by molecular testing.

Prenatal diagnosis is important in order to prepare the parents for the possible outcomes $(14,15)$. It is difficult to accept the potential illness of an unborn child. With 3D or $4 \mathrm{D}$ ultrasound, the anomalies can be visualized, and parents can accept the potential illness (16, 17). The use of $4 \mathrm{D}$, real-time ultrasound gives physicians the possibility to discuss the disease and counsel the patients with the help of images that are more understandable to the general population $(6,7,17)$.

$2 \mathrm{D}$ ultrasound is very important in screening for skeletal dysplasia. Their low incidence, large variability of characteristics, and, in most cases, lack of family history make the diagnosis of skeletal dysplasias difficult.

Conflict of interest statement: Authors declare no conflict of interest. ne i hipoplazija srednjeg dijela lica, kratki i mali prsti, tanki splošteni kralješci, kratka rebra, kratke kosti, kratak i zakrivljen femur (u obliku "telefonske slušalice“), makrokranija, normalna duljina trupa te normalna mineralizacija kostiju i izostanak fraktura. Povezana je s abnormalnostima mozga, a u $50 \%$ bolesnika prisutan je i polihidramnion (11). Novorođenčad s tanatoforičnom displazijom rađa se kao mrtvorođena ili umire ubrzo nakon rođenja zbog teške respiratorne insuficijencije uzrokovane smanjenim kapacitetom prsnog koša i hipoplastičnim plućima $(12,13)$.

Heterozigotna ahondroplazija ima autosomno dominantni način nasljeđivanja. Riječ je o displaziji kratkih udova (do 20. tjedna gestacije) s tipičnim obilježjima poput rizomeličnog skraćenja ruku i nogu, povećanog neurokranija, izraženih čeonih izbočina, znatne makrokranije, zaravnanog hrpta nosa, hipoplazije srednjeg dijela lica, smanjenog anteroposteriornog promjera prsnog koša te protrudiranog abdomena.

U prvog bolesnika konačna je dijagnoza bila potvrđena patohistološkim pregledom i dijagnozom. U drugoga je dijagnoza postavljena nakon rođenja na temelju tipičnih morfoloških obilježja, ali konačna se dijagnoza mora tek potvrditi molekularnim testiranjem.

Prenatalna dijagnoza važna je da bi se roditelji pripremili na mogući ishod $(14,15)$. Roditeljima je teško prihvatiti bolest nerođena djeteta. Zahvaljujući 3D ultrazvuku ili 4D ultrazvuku, anomalije se u fetusa mogu vizualizirati, što roditeljima može pomoći da prihvate poremećaj kod svojeg djeteta $(16,17)$. Upotreba $4 \mathrm{D}$ ultrazvuka sa snimanjem u stvarnom vremenu liječnicima olakšava razgovor s roditeljima jer im mogu pokazati slike koje su razumljivije općoj populaciji (6, $7,17)$.

2D ultrazvuk iznimno je važan u probiru na skeletnu displaziju. Malena incidencija, velika varijabilnost te, $u$ većini slučajeva, izostanak skeletne displazije u obiteljskoj anamnezi otežavaju postavljanje ove dijagnoze.

Izjava o sukobu interesa: Autori izjavljuju da nisu u sukobu interesa. 


\section{REFERENCES / LITERATURA}

1. Kurjak A, Bonilla F, Marton I. Skeletne displazije. U: Kurjak A (ur.). Ultrazvuk u ginekologiji i perinatologiji. Zagreb: Medicinska naklada; 2007., str. 724-40.

2. Kurjak A, Kos M. Ultrazvučna dijagnostika fetalnih malformacija. U: Kurjak A (ur.). Ginekologija i perinatologija II. Varaždinske Toplice: Tonimir; 2003., str. 217-9.

3. Barkova E, Mohan U, Chitayat D, Keating S, Toi A, Frank J i sur. Fetal skeletal dysplasia in a tertiary care center: radiology, pathology, and molecular analysis of 112 cases. Clin Genet. 2015;87(4):330-7.

4. Polák P, Baxová A, Křepelová A, Balák M. [Prenatal diagnosis of skeletal dysplasia in first trimester of pregnancy X-linked dominant chondrodysplasia punctata]. Ceska Gynecol. 2014;79 (3):193-7.

5. Schramm T, Gloning KP, Minderer S i sur. Prenatal sonographic diagnosis of skeletal dysplasias. Ultrasound Obstet Gynecol. 2009;34(2):160-70.

6. Nol AE, Brown RN. Advences in evaluating the fetal skeleton. Int J Womens Health. 2014;6:489-500.

7. International Working Group on Constitutional Disease of Bone. International nomenclature and classification of the osteochondrodysplasias (1997). Am J Med Genet. 1998;79(5): 376-82.

8. Warman ML, Cormier-Daire V, Hall C, Krakow D, Lachman R, LeMerrer M i sur. Nosology and classification of genetic skele- tal disorders: 2010 revision. Am J Med Genet A. 2011;155A (5):943-68.

9. Kronenberg HM. Developmental regulation of the growth plate. Nature. 2003;423(6937):332-6.

10. Cohen MM Jr. The new bone biology: pathologic, molecular, and clinical correlates. Am J Med Genet A. 2006;140(23): 2646-706.

11. Thomas RL, Hess LW, Johnson TR. Prepartum diagnosis of limb-shortening defects with associated hydramnios. Am J Perinatol. 1987;4(4):293-9.

12. Vogt C, Blaas HG. Thanatophoric dysplasia: autopsy findings over a 25-year period. Pediatr Dev Pathol. 2013;16(3):160-7.

13. Davanageri RS, Shokeen PD, Bannur HB, Patil KP. Thanatophoric dysplasia type I: a rare case report at fetal autorsy. J Lab Physicians. 2014;6(2):121-3.

14. Hasegawa K, Tanaka H. Children with short-limbed short stature in pediatric endocrinological services in Japan. Pediatr Int. 2014;56(6):809-12.

15. Parilla BV, Leeth EA, Kambich MP, Chilis P, MacGregor SN. Antenatal detection of skeletal dysplasias. J Ultrasound Med. 2003;22(3):255-8.

16. Krakow D, Williams J 3., Poehl M, Rimoin DL, Platt LD. Use of three-dimensional ultrasound imaging in the diagnosis of prenatal-onset skeletal dysplasias. Ultrasound Obstet Gynecol. 2003;21(5):467-72.

17. Vasilj O, Mišković B. Diagnosis and counseling of thanatophoric dysplasia with four-dimensional ultrasound. J Matern Fetal Neonatal Med. 2012;25(12):2786-8.

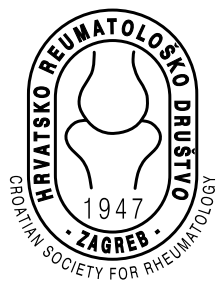

